\title{
PENINGKATAN PRESTASI BELAJAR MATERI BILANGAN BERPANGKAT MELALUI MODEL DISCOVERY LEARNING
}

\author{
Mujiyanto \\ Guru SMP Negeri 1Cawas Klaten \\ mujiyanto.spd2@gmail.com
}

\begin{abstract}
This research is motivated by the unoptimally the mastery of the material is still not optimal exponential number among learners and implementation Discovery learning in mathematic learning material on the exponential number of learners class IX A State of Junior High School One Cawas Klaten second semester of academic year 2014/2015. This study aimed to describe the optimization of mastery of the exponential number through Discovery learning approach in learning of mathematic. Subject and source of research data is a total of 32 learners. Methods of data collection using observation, documentation, and testing. Analysis of data using a critical and comparative analysis. Indicators of success using the criteria limit minimal is 80 and the target class completeness 100\%. Research procedure uses cycles. From the results of research and discussion is known that the data obtained from pre cycle until the second cycle, obtained achievement progress data obtained from pre cycle until the second cycle, obtained advances learning achievements of learners in mathematics with matter exponential number, the pre cycle average of 77 and the cycle I average of 83 and the second cycle by an average of 92. from this data, it seems clear that an increase in the average value of pre cycle to a first cycle of six figures (7.8\%), from the first cycle to the second cycle occurs an increase of 9 numbers (10.8\%), from the second cycle pasiklus to an increase of 15 points (19.5\%). The highest value pre cycle stage by 86 and 90 as well as the first cycle of the second cycle of 98. It is clear that from the stage to the first cycle pre cycle an increase of 4 digits (4.7\%), from the first cycle to the second cycle an increase of 8 digits (8.9\%), and the second cycle of pre cycle to an increase of 12 points (14\%). The lowest scores were obtained for 66 pre cycle stage and the first cycle of 72 and the second cycle of 88. thus, can be affirmed that the step of the first cycle pre cycle to an increase of 6 figures (9.1\%), from the first cycle to the second cycle there is an increase amounting to 16 points $(22.2 \%)$, and the second cycle of pre cycle to an increase of 22 points (33.3\%). The percentage of mastery learning from pre cycle obtained by $34 \%$ and the first cycle was obtained by $66 \%$ and the second cycle of $100 \%$. It seems clear that from the stage to the first cycle pre cycle an increase of $32 \%$, from the first cycle to the second cycle an increase of $34 \%$, and from the second cycle pre cycle to an increase of $66 \%$. Thus, the learning achievements of learners in mathematics learning with the exponential number of pre cycle material to the second cycle brought a significant rise.
\end{abstract}

Keywords: Discovery learning, academic achievement, the exponential number. 


\section{PENDAHULUAN}

Discovery Learning adalah proses pembelajaran yang atter in the final form, but rather is required to organize it him self' (Lefancois dalam Emetembun, 1986:103). Yang menjadikan dasar ide Bruner ialah pendapat dari Piaget yang menyatakan bahwa anak harus berperan aktif dalam belajar di kelas. Discovery Learning mempunyai prinsip yang sama dengan inkuiri (inquiry) dan Problem Solving. Tidak ada perbedaan yang prinsipil pada ketiga istilah ini, pada Discovery Learning lebih menekankan pada ditemukannya konsep atau prinsip yang sebelumnya tidak diketahui.Perbedaannya dengan Discovery ialah bahwa pada Discovery masalah yang diperhadapkan kepada siswa semacam masalah yang direkayasa oleh guru. Sedangkan pada inkuiri masalahnya bukan hasil rekayasa, sehingga siswa harus mengerahkan seluruh pikiran dan keterampilannya untuk mendapatkan temuan-temuan di dalam masalah itu melalui proses penelitian, sedangkan Problem Solving lebih memberi tekanan pada kemampuan menyelesaikan masalah. Akan tetapi prinsip belajar yang nampak jelas dalam Discovery Learning adalah materi atau bahan pelajaran yang akan disampaikan atau tidak disampaikan dalam bentuk final akan tetapi siswa sebagai siswa didorong untuk mengidentifikasi apa yang ingin diketahui dilanjutkan dengan mencari informasi sendiri kemudian mengorgansasi atau membentuk (konstruktif) apa yang mereka ketahui dan mereka pahami dalam suatu bentuk akhir

Dari uraian di atas, peneliti tertarik untuk melakukan penelitian berjudul: "Peningkatan Prestasi Belajar Materi Bilangan Berpangkat melalui Pendekatan Discovery Learning dalam Pembelajaran Matematika pada Peserta Didik Kelas IXA SMP Negeri 1 Cawas Klaten Semester Gasal Tahun Pelajaran 2015/2016".

Permasalahan dalam penelitian ini, yaitu : Apakah melalui pendekatan discovery learning dalam pembelajaran matematika dapat meningkatkan prestasi belajar materi bilangan berpangkat pada peserta didik di SMP Negeri 1 Cawas Klaten semester gasal tahun pelajaran 2015/2016? Selanjutnya, tujuan yang hendak dicapai dalam penelitian ini, sebagai berikut: Tujuan umum, ingin mengetahui gambaran pelaksanaan pembelajaran Matematika di SMP Negeri 1 Cawas Klaten, dan ttujuan khusus, ingin mengetahui dampak penerapan pendekatan Discovery learning dalam upaya mengoptimalisasi prestasi belajar matematika materi bilangan berpangkat pada peserta didik IX A SMP Negeri 1 Cawas Klaten tahun pelajaran 2015/2016. sedangkan manfaat yang diharapkan, manfaat yeoritis, yaitu mendapatkan teori tentang peningkatan penguasaan materi dalam pembelajaran Matematika yang dapat dikembangkan oleh guru yang lain, dan engan penelitin tindakan kelas tentang kontekstual dalam pembelajaran Matematika yang dapat dikembangkan pada penelitian sejenis berikutnya, sedangkan manfaat mraktis, antara lain bagi peserta didik untuk selalu mengoptimalisasi penguasaan yang lebih baik dan berpartisipasi aktif dalam pembelajaran materi bilangan berpangkat mata pelajaran matematika, dan bagi guru matematika SMP dapat dipergunakan sebagai daya dukung dan pentingnya memperhatikan materi ajar dan pendekatan kontekstual melalui pembelajaran yang sesuai dengan indikator khususnya bilangan berpangkat yang berdampak positif terhadap optimalisasi penguasaan materi pelajaran dan hasil belajar peserta didik, serta bagi sekolah SMP Negeri 1 Cawas Klaten untuk membangun dan mengoptimalkan kinerja guru, proses pembelajaran, dan mutu hasil belajar peserta didik. 
Berdasarkan latar belakang masalah dan perumusan masalah dapat diajukan hipotesis tindakan, yaitu: melalui pendekatan discovery learning dalam pembelajaran matematika dapat meningkatkan prestasi belajar materi bilangan berpangkat pada peserta didik SMP Negeri 1 Cawas Klaten semester gasal tahun pelajaran 2015/2016.

\section{METODE}

Penelitian tindakan kelas ini berlangsung selama tiga bulan, dimulai 05 Januari sampai dengan 04 April 2016.. Penelitin ini dilakukan di SMP Negeri 1 Cawas Klaten semester gasal tahun pelajaran 2015/2016. Subjek penelitian adalah siswa IX A SMP Negeri 1 Cawas Klaten semester gasal tahun pelajaran 2015/2016 khusus mata pelajaran Matematika dengan materi bilangan berpangkat sebanyak 32 siswa. Teknik pengumpulan data menggunakan angket motivasi, observasi selama dan setelah dilaksanakan pembelajaran, dokumentasi, dan tes tertulis. Validitas data, apabila menunjukkan bukti nyata ada peningkatan dalam pembelajaran, maka data yang digunakan adalah valid. Penelitian ini adalah penelitian tindakan kelas, jadi tidak perlu menggunakan analisis statistik untuk menguji validitas data.

Teknik analisis data yang digunakan dalam penelitian ini adalah analisis kritis dan analisis komparatif. Analisis kritis kegiatan mengungkap kelemahan kelebihan peserta didik dan guru dalam proses pembelajaran berdasarkan kriteria, hasilnya dijadikan dasar dalam penyusunan perencanaan tindakan untuk tahap berikutnya. Analisis kritis melalui kegiatan tes. Sedangkan eknik komparatif yang dimaksud dalam penelitian ini adalah memadukan data penelitian deskripsi awal (prasiklus), siklus pertama dan kedua. Hasil komparasi tersebut untuk mengetahui keberhasilan maupun kekurangberhasilan dalam setiap siklusnya.

Model tindakan menggunakan model Kemmis dan Taggart. Model ini menggunakan siklus sistem spiral, terdiri dari empat komponen, yaitu rencana, tindakan, observasi dan refleksi (Suwandi, 2009). Peneliti menetapkan indikator kinerja dari prasiklus hingga siklus II, bila sudah optimal atau ada peningkatan partisipasi aktif dan perubahan sikap, kterampilan, dan intelektual, maka tindakan dihentikan. Intinya ada peningkatan hasil belajar peserta didik lebih baik sesuai kriteria ketuntasan minimal sebesar 80 dan ketuntasan kelas 100\%.

\section{HASIL DAN PEMBAHASAN}

Suasana pembelajaran pada kondisi awal atau sebelum tindakan dilaksanakan mulai dari observasi guru dalam pembelajaran, kegiatan guru dalam mempersiapkan kelas untuk pembelajaran, motivasi belajar peserta didik dan prestasi belajar peserta didik belum optimal. Hal ini tampak pada saat peserta didik menerima materi antusiasnya rata-rata masih rendah, perhatian pada penjelasan guru tampak rendah, masih banyak peserta didik yang berbicara sendiri, dan kurang peduli pada kelasnya, guru dalam menyampaikan materi kurang menarik, apersepsi dan motivasi pada peserta didik hanya sekedar apa adanya, dan sebagainya. Hal ini mengakibatkan pembelajaran tidak menarik di hadapan peserta didik, yang mengakibatkan penguasaan materi ajar dan prestasi belajarnya juga belum optimal.

Tahap prasiklus, yang pernah dilaksanakan oleh guru adalah observasi guru dalam pembelajaran mulai dari menyampaikan tujuan pembelajaran hingga suasana kelas mencapai klasifikasi penilaian cukup atau sebesar $60 \%$, tetapi belum optimal, karena peneliti menetapkan 
batas minimal $80 \%$, ada beberapa kegiatan guru dalam pembelajaran yang masih harus ditingkatkan/ dioptimalkan, seperti menyampaikan tujuan, apersepsi, memotivasi peserta didik, inovasi dalam penyampaian materi pembelajaran, pembimbingan belajar peserta didik, mengumpulkan dan memeriksa tugas peserta didik, meningkatkan antusias guru dan peserta didik, pengelolaan waktu pembelajaran belum sesuai rencana, dan pencapaian tujuan juga belum ooptimal, untuk itu perlu ditindaklanjuti pada siklus I.

Tahap prasiklus, yang pernah dilaksanakan oleh guru adalah observasi guru dalam mempersiapkan kelas untuk pembelajaran mulai dari kelas yang bersih dan sehat hingga suasana kelas yang nyaman untuk pembelajaran mencapai klasifikasi penilaian cukup atau sebesar $56 \%$, tetapi belum optimal, karena peneliti menetapkan batas minimal $80 \%$, maka perlu ditindaklanjuti pada siklus I. tahap prasiklus, secara terperinci motivasi peserta didik pada tahap prasiklus (sebelum ada tindakan) dalam pembelajaran matematika dengan materi bilangan berpangkat sebanyak 11 peserta didik (34\%) sudah melampaui kriteria ketuntansan minimal sebesar 80, dan sisanya sebanyak 21 peserta didik $(66 \%)$ belum/ tidak tercapai motivasi peserta didik dalam pembelajaran matematika dengan materi bilangan berpangkat, diperoleh nilai rata-rata sebesar 75 dalam klasifikasi penilaian adalah tidak tercapai atau belum tuntas, karena peneliti menetapkan kriteria opminimal sebesar 80. Hal ini perlu ditindaklanjuti pada siklus I

Prestasi belajar peserta didik dalam pembelajaran matematika tahap prasiklus dengan materi bilangan berpangkat, diperoleh nilai rata-rata 77 dalam klasifikasi penilaian belum tercapai/ belum tuntas atau belum mencapai batas ketuntasan minimaal sebesar 80 . Secara terperinci prestasi belajar peserta didik prasiklus (sebelum ada tindakan) dalam pembelajaran matematika dengan materi bilangan berpangkat klasifikasi penilaian tercapai/ terlampaui sebanyak 11 peserta didik (34\%), dan sisanya sebanyak 21 peserta didik (66\%) belum tercapai/ tidak tuntas, nilai tertinggi sebesar 86 , dan nilai terendah sebesar 66 , karena peneliti menetapkan kriteria ketintasan minimal 80, dan ketuntasan kelas sebesar 100\%, maka tahap kondisi awal ini akan ditindaklanjuti kegiatan atau tindakan siklus I.

Pembelajaran sudah dibagi menjadi kelompok-kelompok kecil, setiap kelompok anggotanya 5 peserta didik. Kondisi pembelajaran sudah tampak antusias, komunikasi dan interaksi antarpeserta didik sudah efektif dan dalam bimbingan guru. Peserta didik berani mengacungkan jari untuk menjawab pertanyaan guru. Kemudian, guru menunjuk seorang peserta didik putri untuk mendemonstraikan hasil kerja kelompoknya, kemudian guru mengamati hasil pekerjaan peserta didik tersebut, guru memberikan dan menyampaikan atau hasilnya pada peserta diskusi, apakah hasil pekerjaan tersebut sudah benar. Semua peserta didik mengamati, mencocokkan pekerjaannnya, ternyata sudah benar, meskipun ada beberapa yang belum benar. Tahap siklus I, yang pernah dilaksanakan oleh guru adalah observasi guru dalam pembelajaran mulai dari menyampaikan materi hingga suasana kelas mencapai klasifikasi penilaian tinggi atau sebesar 71,4\%, belum optimal atau belum tuntas/ tidak tercapai, karena peneliti menetapkan batas kriteria ketuntasan minimal 80\%, maka perlu ditindaklanjuti pada siklus II. Ada beberapa hal yang masih perlu ditingkatkan adalah pada kegiatan guru dalam memotivasi belajar peserta didik, mengumpulkan tugas peserta didik, dan mendorong antusias peserta didik.

Hasil observasi guru dalam mempersiapkan kelas untuk pembelajaran mulai dari kelas yang bersih dan sehat hingga suasana kelas yang nyaman untuk pembelajaran mencapai 
sebesar $72 \%$, belum optimal, karena peneliti menetapkan batas minimal $80 \%$, masih ada yang perlu ditingkatkan yaitu meja dan kursi peserta didik belum lengkap, sarana prasarana belum optimal dimanfaatkan dalam pembelajaran, media dan belum dimanfaatkan dalam pembelajaran, penerangan yang nelum memadai dan mendukung pembelajaran, maka perlu ditindaklanjuti pada siklus II. Secara terperinci motivasi peserta didik pada siklus I (setelah ada tindakan) dalam pembelajaran matematika dengan materi bilangan berpangkat klasifikasi penilaian tuntas atau terlampaui sebanyak 21 peserta didik (66\%), sisanya sebanyak 11 peserta didik (34\%) belum/ tidak mencapai/ melampaui kriteria ketuntasan minimal sebesar $80 \%$, motivasi peserta didik dalam pembelajaran matematika dengan materi bilangan berpangkat, diperoleh nilai rata-rata 81; nilai tertinggi sebesar 88; nilai terendah sebesar 70 dalam klasifikasi belum optimal, karena peneliti menetapkan minimal sebesar 80, maka perlu ditindaklanjutI siklus berikutnya, yaitu siklus II. selanjutnya, siklus I ini prestasi belajar peserta didik dalam pembelajaran matematika dengan materi bilangan berpangkat, diperoleh nilai rata-rata 83; nilai tertinggi sebesar 90; nilai terendah sebesar 72 dan ketuntasan kelas sebesar 76\%, karena peneliti menetapkan kriteria ketintasan minimal 80, dan ketuntasan kelas sebesar $100 \%$, maka siklus I ini perlu ditindaklanjuti siklus II.

.Hasil observasi guru dalam pembelajaran mulai dari menyampaikan materi hingga suasana kelas mencapai klasifikasi penilaian sangat tinggi atau sebesar 85,7\%, sudah optimal, suasana kelas kondusif yaitu guru dan peserta didik memiliki antusias atau motivasi yang tinggi, pengelolaan waktu pembelajaran efektif, kegiatan pembelajaran sesuai rencana, dan tujuan tercapai. Tahap siklus II, hasi; observasi guru dalam mempersiapkan kelas untuk pembelajaran mulai dari kelas yang bersih dan sehat hingga suasana kelas yang nyaman untuk pembelajaran mencapai dan atau melampaui, sehingga dinyatakan memenuhi klasifikasi kriteeria ketuntasan minimal sebesar 90\%, secara keseluruhan kelas pembelajaran sudah optimal.

Motivasi peserta didik dalam pembelajaran matematika dengan materi bilangan berpangkat, diperoleh nilai rata-rata 90, nilai tertinggi sebesar 96, nilai terendah sebesar 86 dalam klasifikasi penilaian sudah optimal, karena peneliti menetapkan sebesar 80 . Secara terperinci motivasi peserta didik pada siklus II (setelah ada tindakan) dalam pembelajaran matematika dengan materi bilangan berpangkat klasifikasi penilaian tercapai/ terlampaui seluruhnya sebanyak 32 peserta didik (100\%). Pada tahap siklus II ini sudah optimal. Pada siklus II, menunjukkan prestasi belajar peserta didik dalam pembelajaran matematika dengan materi bilangan berpangkat, diperoleh nilai rata-rata 92 nilai tertinggi 98 , nilai terendah 88 , dan ketuntasan kelas sebesar 100\%, secara keseluruhan sebanyak 32 peserta didik (100\%) tuntas/ terlampaui.

Proses pembelajaran sesuai dengan Permendikbud Nomor 65 tahun 2013 tentang Standar Proses Pendidikan Dasardan Menengah,sepenuhnya diarahkan pada pengembangan ranah sikap, pengetahuan, dan keterampilan secara utuh melalui pendekatan saintifik dan diperkuat dengan menerapkan beberapa pendekatan pembelajaran diantaranya pembelajaran berbasis penyingkapan/ penelitian (discovery/ inquiry learning). Untuk memahami pendekatan ini dan penerapannya pada pembelajaran Matematika SMP/MTs, yang diharapkan dapat meningkatkan penguasaan materi dan prestasi belajar peserta didik. Faktor yang memengaruhi proses pembelajaran terdiri dari faktor internal dan eksternal. Faktor internal adalah faktor-faktor 
yang berkaitan dengan pribadi guru sebagai pengelola kelas. Guru harus dapat melaksanakan proses pembelajaran, oleh sebab itu guru harus memiliki persiapan mental, kesesuaian antara tugas dan tanggung jawab, penguasaan bahan, kondisi fisik, dan motivasi kerja. Faktor eksternal adalah kondisi yang timbul atau datang dari luar pribadi guru, antara lain keluarga dan lingkungan pergaulan di masyarakat. Faktor lingkungan, yang dimaksud adalah faktor lingkungan alam, lingkungan sosial, dan lingkungan sekolah.

Diperoleh kemajuan guru dalam pembelajaran, pada prasiklus sebesar $60 \%$, siklus I sebesar 71,4\% dan siklus II sebesar 85,7\%. Dari data ini menunjukkan bahwa ada kemajuan dari prasiklus ke siklus I sebesar 11,4\%, kemudian dari siklus I ke siklus II terjadi kenaikan sebesar 14,3\% serta dari prasiklus ke siklus II sebesar 25,7\%. Dengan demikian, hasil obervasi guru dalam pembelajaran menunjukkan peningkatan yang signifikan. Data yang diperoleh dari prasiklus hingga siklus II, diperoleh kemajuan guru dalam mempersiapkan kelas untuk pembelajaran, pada prasiklus sebesar 56\%, siklus I sebesar 72\% dan siklus II sebesar 90\%. Dari data ini menunjukkan bahwa ada kemajuan dari prasiklus ke siklus I sebesar 16\%, kemudian dari siklus I ke siklus II terjadi kenaikan sebesar 18\% serta dari prasiklus ke siklus II sebesar 34\%. Dengan demikian, hasil obervasi guru dalam mempersiapkan kelas untuk pembelajaran menunjukkan peningkatan yang signifikan, karena proses pembelajaran yang berlangsung menunjukkan kenaikan prestasi belajar yang meyakinkan dengan menggunakan pendekatan Discovery learning.

Data yang diperoleh dari prasiklus hingga siklus II, diperoleh kemajuan motivasi peserta didik dalam pembelajaran matematika dengan materi bilangan berpangkat, pada prasiklus rata-rata sebesar 75 dan siklus I rata-rata sebesar 81 serta siklus II sebesar 90. Dari data ini, tampak jelas bahwa terjadi kenaikan dari prasiklus ke siklus I sebesar 6 angka (8\%), dari siklus I ke siklus II terjadi kenaikan sebesar 9 angka $(11,1 \%)$, dari prasiklus ke siklus II terjadi kenaikan sebesar 15 angka (20\%). Nilai tertinggi pada tahap prasiklus diperoleh sebesar 84 dan siklus I sebesar 88 serta siklus II sebesar 96 maka dapat diketahui bahwa dari prasiklus ke siklus I terjadi kenaikan 4 angka (4,8\%), dari siklus I ke siklus II terjadi kenaikan sebesar 8 angka (9,1\%), dan dari mprasiklus ke siklus II terjadi kenaikan sebesar 12 angka (14,3\%). Nilai terendah pada prasiklus sebesar 60 dan pada siklus I sebesar 70 serta pada siklus II sebesar 86, maka dapat ditegaskan bahwa terjadi kenaikan dari prasiklus ke siklus I sebesar 10 angka (16,7\%), dari siklus I ke siklus II terjadi kenaikan sebesar 16 angka (22,9\%), dan dari prasiklus ke siklus II terjadi kenaikan sebesar 16 angka (43,3\%). Persentase optimalisasi motivasi pada tahap prasiklus diperoleh sebesar 34\%, siklus I sebesar 66\%, dan siklus II sebesar 100\%. Dengan demikian, dapat ditegaskan bahwa terjadi kenaikan dari prasiklus ke siklus I sebesar 32\%, dari siklus I ke siklus II terjadi kenaikan sebesar 34\%, dan dari prasiklus ke siklus II terjadi kenaikan sebesar 66\%. Dengan demikian, motivasi peserta didik dalam pembelajaran matematika dengan materi bilangan berpangkat dari prasiklus hingga siklus II terjadi kenaikan yang signifikan.

Data yang diperoleh dari prasiklus hingga siklus II, diperoleh kemajuan prestasi belajar peserta didik dalam pembelajaran matematika dengan materi bilangan berpangkat, pada prasiklus rata-rata sebesar 77 dan siklus I rata-rata sebesar 83 serta siklus II rata-rata sebesar 92. Dari data ini, tampak jelas bahwa terjadi kenaikan rata-rata nilai dari prasiklus ke siklus I sebesar 6 angka (7,8\%), dari siklus I ke siklus II terjadi kenaikan sebesar 9 angka (10,8 \%), 
dari pasiklus ke siklus II terjadi kenaikan sebesar 15 angka (19,5\%). Nilai tertinggi tahap prasiklus sebesar 86 dan siklus I sebesar 90 serta siklus II sebesar 98. Tampak jelas bahwa dari tahap prasiklus ke siklus I terjadi kenaikan sebesar 4 angka (4,7\%), dari siklus I ke siklus II terjadi kenaikan sebesar 8 angka (8,9\%), dan dari prasiklus ke siklus II terjadi kenaikan sebesar 12 angka (14\%). Nilai terendah tahap prasiklus diperoleh sebesar 66 dan siklus I sebesar 72 serta siklus II sebesar 88. dengan demikian, dapat ditegaskan bahwa dari tahap prasiklus ke siklus I terjadi kenaikan sebesar 6 angka (9,1\%), dari siklus I ke siklus II terjadi kenaikan sebesar 16 angka (22,2\%), dan dari prasiklus ke siklus II terjadi kenaikan sebesar 22 angka (33,3\%). Persentase ketuntasan belajar mulai dari prasiklus diperoleh sebesar 34\% dan siklus I diperoleh sebesar 66\% serta siklus II sebesar 100\%. Tampak jelas bahwa dari tahap prasiklus ke siklus I terjadi kenaikan sebesar 32\%, dari siklus I ke siklus II terjadi kenaikan sebesar 34\%, dan dari prasiklus ke siklus II terjadi kenaikan sebesar 66\%. Dengan demikian, prestasi belajar peserta didik dalam pembelajaran matematika dengan materi bilangan berpangkat dari prasiklus hingga siklus II terjadi kenaikan yang signifikan.

Dalam konsep belajar, sesungguhnya Discovery learning merupakan pembentukan kategori-kategori atau konsep-konsep, yang dapat memungkinkan terjadinya generalisasi. Sebagaimana teori Bruner tentang kategorisasi yang nampak dalam Discovery, bahwa Discovery adalah pembentukan kategori-kategori, atau lebih sering disebut sistem-sistem coding. Pembentukan kategori-kategori dan sistem-sistem coding Bruner mengatakan bahwa proses belajar akan berjalan dengan baik dan kreatif jika guru memberikan kesempatan kepada peserta didik untuk menemukan suatu konsep, teori, aturan, atau pemahaman melalui contoh-contoh yang ia jumpai dalam kehidupannya (Budiningsih, 2005:41). Menurut Syah (2004:244) dalam mengaplikasikan Discovery Learning di kelas, ada beberapa prosedur yang harus dilaksanakan dalam kegiatan belajar mengajar secara umum.

Setelah dilakukan stimulasi langkah selanjutya adalah guru memberi kesempatan kepada peserta didik untuk mengidentifikasi sebanyak mungkin agenda-agenda masalah yang relevan dengan bahan pelajaran, kemudian salah satunya dipilih dan dirumuskan dalam bentuk hipotesis (jawaban sementara atas pertanyaan masalah) (Syah 2004:244). Ketika eksplorasi berlangsung guru juga memberi kesempatan kepada para peserta didik untuk mengumpulkan informasi sebanyak-banyaknya yang relevan untuk membuktikan benar atau tidaknya hipotesis (Syah, 2004:244). Pada tahap ini berfungsi untuk menjawab

Discovery learning adalah proses pembelajaran yang atter in the final form, but rather is required to organize it him self' (Lefancois dalam Emetembun, 1986:103). Yang menjadikan dasar ide Bruner ialah pendapat dari Piaget yang menyatakan bahwa anak harus berperan aktif dalam belajar di kelas. Discovery Learning mempunyai prinsip yang sama dengan inkuiri (inquiry) dan Problem Solving. Tidak ada perbedaan yang prinsipil pada ketiga istilah ini, pada Discovery Learning lebih menekankan pada ditemukannya konsep atau prinsip yang sebelumnya tidak diketahui.Perbedaannya dengan Discovery ialah bahwa pada Discovery masalah yang diperhadapkan kepada peserta didik semacam masalah yang direkayasa oleh guru agar dapat mencapai kegiatan belajar dan prestasi be;ajar yang optimal.

Terkait dengan kondisi belajar dan prestasi peserta didik/ siswa, ada beberapa pendapat berikut ini Skinner (Gunarsa. 1995:118) berpendapat belajar adalah suatu perilaku, pada saat orang belajar, maka responnya menjadi lebih baik. Sedangkan Witherington menyatakan, 
bahwa belajar itu kompleks dan harus melalui bermacam-macam kegiatan yaitu : (1) anak harus berbuat melakukan apa yang dipelajarinya; (2) mendengarkan, mengingat, membaca buku; (3) berpikir, menganalisis dan menggunakan pengalaman masa lampau Menurut Habeyb (1983:296), menyatakan bahwa belajar adalah suatu perubahan tingkah laku yang secara keseluruhan sebagai hasil pengalaman individu untuk memperoleh suatu perubahan tingkah laku yang baru secara keseluruhan sebagai hasil pengalaman individu itu sendiri dalam berinteraksi dengan lingkungan. Sedangkan menurut Oemar Hamalik. (1994:36), menyatakan bahwa belajar adalah merupakan suatu proses, suatu kegiatan dan bukan suatu hasil atau tujuan. Belajar bukan hanya mengingat, akan tetapi lebih luas daripada itu, yakni mengalami. Hasil belajar bukan suatu penguasaan hasil latihan, melainkan perubahan kelakuan.

Lebih lanjut, Mustaqim (2008:34), menyatakan bahwa belajar adalah suatu aktifitas atau usaha yang disengaja, aktifitas tersebut menghasilkan perubahan, berupa sesuatu yang baru baik yang segera nampak atau tersembunyi tetapi juga hanya berupa penyempurnaan terhadap sesuatu yang pernah dipelajari, perubahan-perubahan itu meliputi perubahan ketrampilan jasmani, kecepatan perceptual, isi ingatan, abilitas berpikir, sikap terhadap nilai-nilai dan inhibisi serta lain-lain fungsi jiwa (perubahan yang berkenaan dengan aspek psikis dan fisik), perubahan tersebut relatif bersifat konstan. Menurut Nasution (1982:38-39), mendefiisikan belajar adalah proses yang melukiskan atau mengubah suatu kegiatan melalui jalan latihan atau belajar adalah perubahan kelakuan berkat pengalaman dan latihan. Menurut Cronbach (Sardiman, 1980 : 50), mengemukakan bahwa belajar adalah perubahan tingkah laku sebagai hasil pengalaman. Menurut Witherington (Sardiman, 1980:51), mendefinisikan belajar adalah suatu perubahan pada kepribadian pada adanya pola sambutan baru, yang dapat berupa pengertian atau pengalaman yang baru.

Menurut Siddiq, dkk. (2008:1-3), menegaskan bahwa belajar adalah suatu aktivitas yang disengaja dilakukan oleh individu agar terjadi perubahan kemampuan diri, dengan belajar anak yang tadinya tidak mampu melakukan sesuatu, menjadi mampu melakukan sesuatu itu, atau anak yang tadinya tidak terampil menjadi terampil. Sedangkan menurut Dimyati dan Mudjiono (2002:7) Belajar merupakan tindakan perilaku siswa yang kompleks. Sebagai tindakan, maka belajar hanya dialami oleh siswa sendiri. Siswa adalah penentu terjadinya proses belajar. Menurut Slameto (1990:142), menyetakan bahwa belajar adalah proses yang diarahkan kepada tujuan, proses perbuatan melalui berbagai pengalaman. Menurut Winkel (Darsono, 2002:4) mengemukakan, bahwa belajar adalah suatu mental atau psikis yang berlangsung dalam interaksi dengan lingkungan, menghasilkan perubahan dalam perubahan, pemahaman, ketrampilan dan nilai sikap yang saling terkait dan mendukung dalam belajar anak.

Menurut Abdulrahman (1993:37), menyatakan bahwa bahwa penggabungan pengertian prestasi dan belajar mengandung pengertian penguasaan atau keterampilan yang dikembangkan oleh mata pelajaran, lazimnya ditunjukkan dengan nilai tes atau angka nilai yang diberikan oleh guru. Bahkan prestasi belajar berarti penguasaan siswa terhadap materi pelajaran tertentu yang diperoleh dari hasil belajar yang dinyatakan dalam bentuk skor setelah mengikuti belajar. Tulus (2004: 81), menegaskan bahwa keberhasilan siswa dalam mencapai prestasi belajar dipengaruhi oleh beberapa faktor yaitu tingkat kecerdasan yang baik, pelajaran sesuai dengan 
bakat yang dimiliki, ada minat dan perhatian yang tinggi dalam pembelajaran, motivasi yang baik dalam belajar, cara belajar yang baik dan strategi pembelajaran yang dikembangkan guru. Suasana keluarga yang mendorong anak untuk maju, selain itu lingkungan sekolah yang tertib, teratur dan disiplin merupakan pendorong dalam proses pencapaian prestasi belajar.

\section{PENUTUP}

Hasil penelitian dan pembahasan tentang "Peningkatan Prestasi Belajar Materi Bilangan Berpangkat melalui Pendekatan Discovery Learning dalam Pembelajaran Matematika pada Peserta Didik Kelas IX A SMP Negeri 1 Cawas Klaten Semester Gasal Tahun Pelajaran 2015/2016", dapat disimpulkan bahwa data yang diperoleh dari prasiklus hingga siklus II, diperoleh kemajuan prestasi belajar peserta didik dalam pembelajaran matematika dengan materi bilangan berpangkat, pada prasiklus rata-rata sebesar 77 dan siklus I rata-rata sebesar 83 serta siklus II rata-rata sebesar 92. Dari data ini, tampak jelas bahwa terjadi kenaikan rata-rata nilai dari prasiklus ke siklus I sebesar 6 angka (7,8\%), dari siklus I ke siklus II terjadi kenaikan sebesar 9 angka (10,8 \%), dari pasiklus ke siklus II terjadi kenaikan sebesar 15 angka (19,5\%). Nilai tertinggi tahap prasiklus sebesar 86 dan siklus I sebesar 90 serta siklus II sebesar 98. Tampak jelas bahwa dari tahap prasiklus ke siklus I terjadi kenaikan sebesar 4 angka (4,7\%), dari siklus I ke siklus II terjadi kenaikan sebesar 8 angka (8,9\%), dan dari prasiklus ke siklus II terjadi kenaikan sebesar 12 angka (14\%). Nilai terendah tahap prasiklus diperoleh sebesar 66 dan siklus I sebesar 72 serta siklus II sebesar 88. dengan demikian, dapat ditegaskan bahwa dari tahap prasiklus ke siklus I terjadi kenaikan sebesar 6 angka $(9,1 \%)$, dari siklus I ke siklus II terjadi kenaikan sebesar 16 angka (22,2\%), dan dari prasiklus ke siklus II terjadi kenaikan sebesar 22 angka (33,3\%). Persentase ketuntasan belajar mulai dari prasiklus diperoleh sebesar 34\% dan siklus I diperoleh sebesar 66\% serta siklus II sebesar 100\%. Tampak jelas bahwa dari tahap prasiklus ke siklus I terjadi kenaikan sebesar 32\%, dari siklus I ke siklus II terjadi kenaikan sebesar 34\%, dan dari prasiklus ke siklus II terjadi kenaikan sebesar 66\%. Dengan demikian, prestasi belajar peserta didik dalam pembelajaran matematika dengan materi bilangan berpangkat dari prasiklus hingga siklus II terjadi kenaikan yang signifikan.

Hasil temuan dan tindakan dapat diimplikasikan dalam bahwa discovery learning diharapkan yang memungkinkan peserta didik mendapat pelayanan yang bersifat perbaikan, pengayaan, dan/atau percepatan serta prestasi belajar sesuai dengan potensi, tahap perkembangan, dan kondisi peserta didik dengan tetap memperhatikan keterpaduan pengembangan pribadi peserta didik yang berdimensi ke-Tuhanan, keindividuan, kesosialan, dan moral. Selanjutnya, Saran penulis, bagi guru, diharapkan penerapan inovasu discovery learning, mengingat dalam pembelajaran Discovery learning peran guru dalam proses pembelajaran merupakan fenomena yang kompleks. Guru lebih banyak berhubungan dengan pola pikir peserta didik di mana setiap peserta didik - siapapun, dimanapun - memiliki setumpuk kata, pikiran, tindakan yang dapat mengubah lingkungan baik di keluarga, di sekolah maupun di masyarakat. Selanjutnya, bagi peserta didik, diharapkan berupaya untuk mempersiapkan diri dan selalu melaksanakan belajar secara mandiri baik secara internal maupun eksternal, baik ketika di dalam kelas maupun di luar kelas, agar dapat menxapai prestasi belajar yang maksimal, terutama setelah menerima pembelajaran dengan menggunakan discovery learning. Dengan demikian peserta didik dapat mengkomunikasikan hasil pekerjaan yang telah disusun baik secara bersama-sama 
dalam kelompok dan atau secara individu dari hasil kesimpulan yang telah dibuat bersama. Kegiatan mengkomunikasikan ini dapat diberikan klarifikasi oleh guru agar supaya peserta didik akan mengetahui secara benar apakah jawaban yang telah dikerjakan sudah benar atau ada yang harus diperbaiki. Hal ini dapat diarahkan pada kegiatan konfirmasi sebagaimana pada standar proses.

\section{DAFTAR PUSTAKA}

Abdurrahman, Abror, 1993. Psikologi Pendidikan. Yogyakarta : PT. Tiara Wacana.

BSNP. 2007. Standar Kompetensi dan Kompetensi Dasar Untuk SMP/MTs Kurikulum Tingkat Satuan Pendidikan Jenjang Pendidikan Dasar dan Menengah. Jakarta

Costa. A.1988. Developing Minds A Resource Bookfor Teaching Thinking. Association for Supervision and Curriculum Development. Alexandria Virginia.

Dahar, R.W .1996. Teori-teori Belajar. Jakarta: Erlangga.

Darsono, Max, 2000. Belajar dan Pembelajaran. Yogyakarta: IKIP Yogyakarta Press.

Departemen Pendidikan Nasional. 2003. Standar Kompetensi Mata Pelajaran Matematika SMP Sekolah Menengah Pertama. Jakarta:BSNP.

Downs, S.S. 1987. “Developing Learning Skills,” informasi Learning Management: Emerging Directions for Learning to learn informasi the workplace, edited by M.E.Cheren. Columbus: Ohio State University.

Gunarsa, Singgih D., 1995. Psikologi Perkembangan Anak dan Remaja. BPK Gunung Mulia. Jakarta

Hamalik, Oemar. 2004. Psikologi Belajar dan Mengajar. Bandung : Sinar Baru Algesindo.

Habeyb, S.F. 1983. Kamus Populer. Jakarta : Nurani.

Mahmud, M. Dimyati, 1993. Psikologi Pendidikan. Yogyakarta : PT. Tiara Wacana.

Mustaqim. 2008. Psikologi Pendidikan. Semarang : Fakultas Tarbiyah IAIN Walisongo Semarang.

Nasution S., 2002. Kurikulum dan Pengajaran. Jakarta : P.T. C.V. Bina Aksara.

Novak, D. and D.B. Gowin. 1985. Learning How to Learn, Second Edition. New York: Cambridge University Press.

Slameto, 1990. Psikologi Belajar. Semarang: IKIP Semarang.

Sujati. 2000. Penelitian Tindakan Kelas. Yogyakarta: Universitas Negeri Yogyakarta.

Suwandi, Sarwiji. 2009. Modul Pendidikan dan Latihan Profesi Guru : Penelitian Tindakan Kelas. Surakarta : UNS.

Syamsudini. 2012. Aplikasi Metode Discovery Learning Dalam Meningkatkan Kemampuan Memecahkan Masalah, Motivasi Belajar dan Daya Ingat Siswa.

Syah, M. 1996. Psikologi Pendidikan Suatu Pendekatan Baru. PT Remaja Rosdakarya, Bandung.

Tulus, Tu'u, 2004. Peran Disiplin Pada Perilaku dan Prestasi Siswa. Jakarta: Grasindo

Undang-Undang Republik Indonesia Nomor 20 Tahun 2003 Tentang Sistem Pendidikan Nasional. 